\title{
Artistic painted decorations on the outside walls of the castles in western Ukraine
}

\author{
Mykola Bevz \\ https://orcid.org/0000-0003-1513-7045 \\ m.bevz@pollub.pl \\ Department of Build Conservation, Faculty of Civil Engineering \\ and Architecture, Lublin University of Technology
}

\begin{abstract}
The article describes the newfound fragments of polychrome paintings in the upper tiers of the southeastern castle tower in Pomoriany (Pomorzany - in polish). The pictures are found on the outside wall of the tower. The polychrome murals are preserved in fragments. The paintings decorated the plastered walls of the at the top two levels of the tower and can be dated roughly to the $17^{\text {th }}$ century. Another mural fragment, discovered on the outside of the north wall of the castle in Yazlivets, is much smaller, but with more vibrant colors. Such exterior castle walls decorating with polychrome paintings are rare in Ukraine. It is proposed to preserve and conserve these fragments of murals. Remains of polychrome art paintings are also found in other castles - in Zhovkva, Pidhirtsi, Stare Selo.
\end{abstract}

Keywords: castles, painting murals, the towns of Pomoriany, Yazlivets, Zhovkva, Stare Selo, the $16-17^{\text {th }}$ century.

\section{Introduction}

Painting mural at the exterior walls of castle buildings is a rare occurrence. The defensive function of the outside castle walls with holes cut for firing the enemy required walls to be strong and reliably thick, not decorated or painted. It became popular in recent times only, when castles lost their defensive value and turned into palace objects. We can find paintings usually from the courtyard, where they were used to create heraldic hand-drawn compositions. Therefore, the detection of fragments of such decorative murals on the outer walls of the castle is an extraordinary event and requires detailed illumination and further thorough study.

Purpose of the article: to present general data on the discovered remains of paintings, to analyze their parameters, and to perform a hypothetical reconstruction of their original state.

\section{Analysis of previous research and methods of the study}

The study is based on our visits to several castles in Western Ukraine and their field-scale research. We did not have a special expedition to study castle architecture. The study was conducted over several years, analyzing and summarizing field research materials and photo-fixation of results. Five castles were found as the objects with polychrome art decoration - in Pomoriany, in Pidhirtsi, in Zhovkva, in Stare Selo (Lviv region) and Yazlivets (Ternopil region).

There are very few scientific publications on the subject of artistic decoration of Western Ukraine castles. Mostly researchers were interested in the plastic decoration of the castles, the remains of which are preserved more. This information is found in the works of A. Czolowski, B. Janusz, O. Matsiuk, V. Vecherskyi, and others $[4,5,12,16]$. We briefly described the polychrome decoration of the Pomoriany Castle in our 2016 article [2].

The research methods consisted of comparing the field studies' information on stored remains of polychrome paint decor with materials from object history. On the basis of this, a hypothesis was made about the 
time of painting decoration, its stylistic features were analyzed, and a hypothesis about its function and hypothetical integral forms were performed.

During fieldwork, we selected samples of plasters and paints for laboratory testing. We plan to dedicate our next publication to the results of laboratory analysis.

\section{Presentation of the research material}

The castle in Pomoriany was built in the $15^{\text {th }}$ century. At that time, he belonged to the Russian family of the Kerdey, in particular, in 1462 voivode of Podillia Hrytsko Kerdeyovych was the owner. Later it belonged to his son Sigismund Kerdey, chief of the Terebovlya, who died in 1498 defending the castle from the Tatar attack [11]. Some preserved stone-built wall fragments can be dated to the $15^{\text {th }}$ century. Although most researchers submit a later date of foundation of the stone castle, considering that it originated in the XVI century [13, p. $122 ; 15,19]$. The castle is built on a low hill among the former swampy valley of the Zolota Lypa river and its tributary Makhnivka. Water surrounded the castle on three sides. Only from the side of the city, it was possible to reach the castle by land. According to our hypothesis, the original castle was built in a square form with an inner courtyard and four corner towers. On the north side of the town, the castle was separated by a moat through which a bridge was constructed.

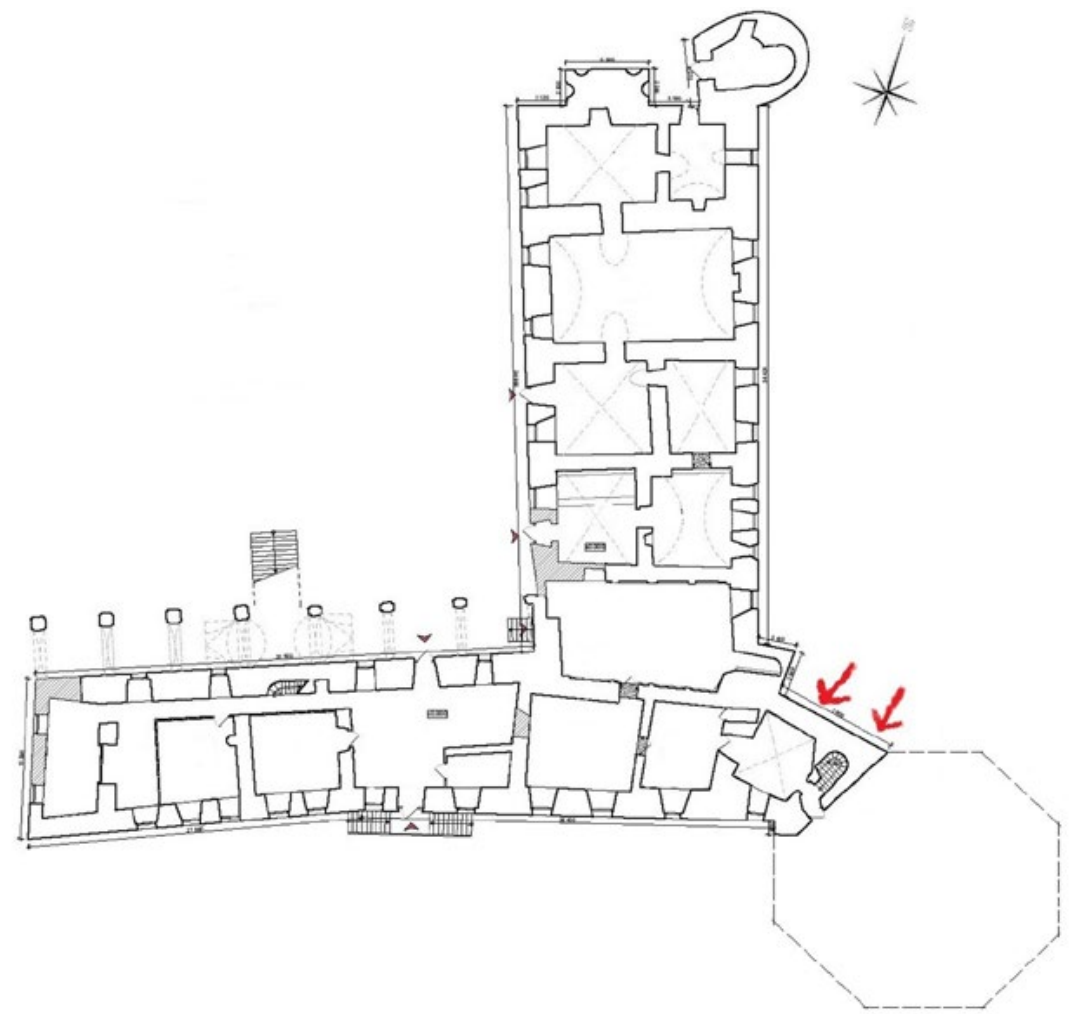

Fig. 1. Plan of the castle in Pomoriany as of 2017. Drawing - by Kalyna Havryliv, Mykola Bevz [7]. The arrow indicates the location of the painted wall, and the dashed line indicates the lost tower.

From publications and historical documents, the following chronology of the castle owners change is traced: the middle and the end of the XV century - the castle belongs to the families of Kerdey and Kerdeyovych; in the 1490s, nobleman Mykola Svynka is mentioned as an owner of a village and a castle [13]; there is also a mention that at the end of the XV century the castle was owned by Zygmunt Senensky of Olesnytsia (apparently due to his marriage to Jan Svynka's daughter Anna) [4]; at the beginning of the XVI century the owner was the Lviv casteman Jan Senensky [19]; castle was in the hands of the Senensky family during the whole XVI century; from 1619 the castle belonged to the Sobieski family; in 1740 the castle was bought by Myhailo Radzywill $[4,19]$; at the end of the XVIII century the castle became the property of the Pruszynski family; in 1879 the 
building was purchased by Stanislav Pototski; the castle belonged to this family until 1939 [4]; in Soviet times the preserved two-storeyed north and west wings of the castle were used as an educational institution. In recent years, the castle is in ruins.
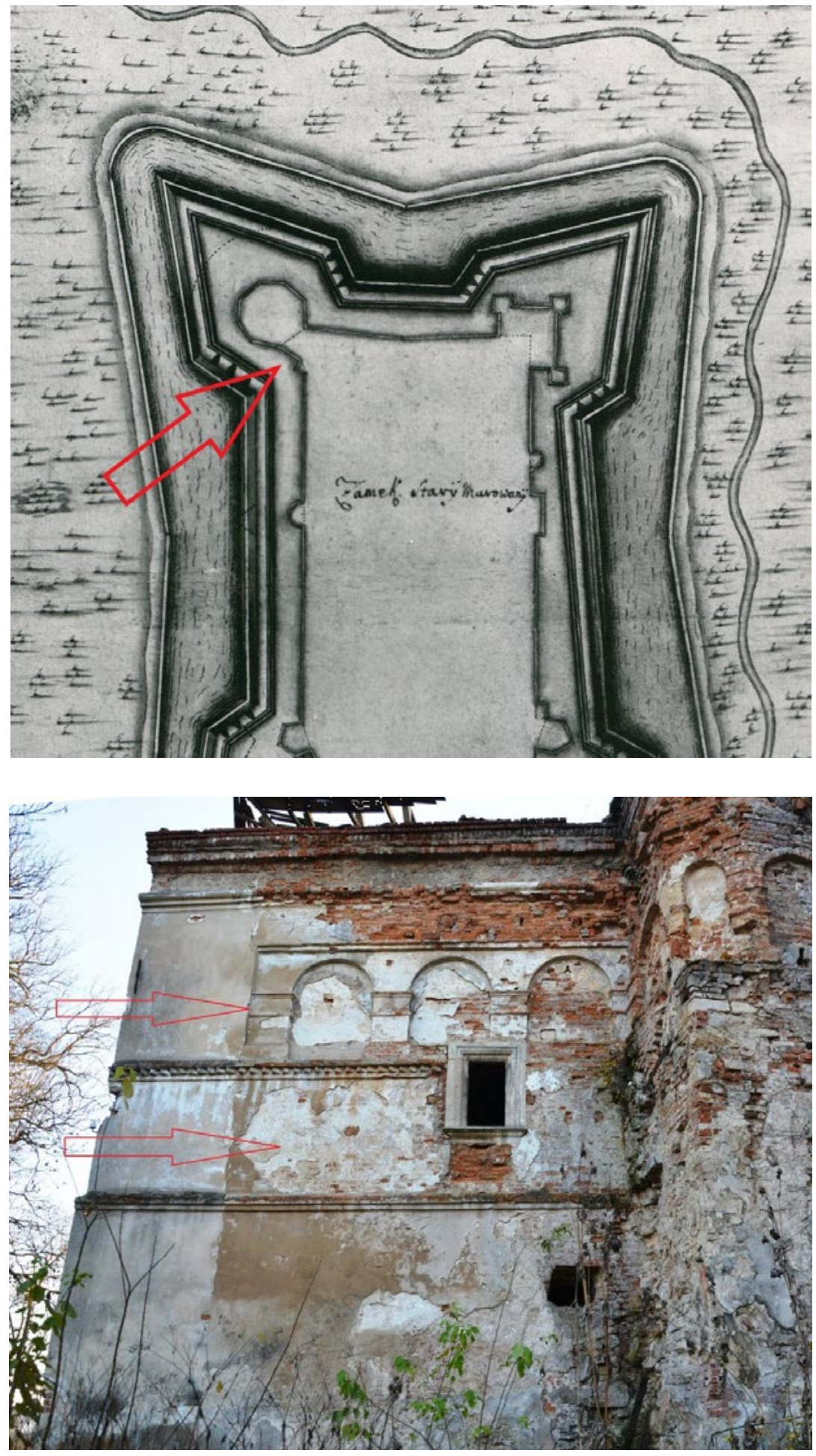

Fig. 2. Drawings of the fortifications of the Pomoriany castle taken from the work of Alexander Czolowski [3]. In the southeast corner, a round tower with facets is marked. The western wall we are exploring is a preserved part of the "neck" to this tower. This wall is marked by an arrow.
Fig. 3. The north wall of the corner tower of the Pomoriany castle. The places where the polychrome paintings preserved are indicated with arrows. Photo by M. Bevz, 2017. 
Unfortunately, the architectural history of the castle has not yet been fully explored. Previous publications have paid attention to the change of owners, and in very general terms, described the restructuring of the object. The architectural biography of the castle and the dates of its remodeling remain unknown. The preserved two wings of the castle were created at different times so that they should be carefully examined and dated. It is unclear when a set of four soil bastions was built around the castle. When was the first park laid?

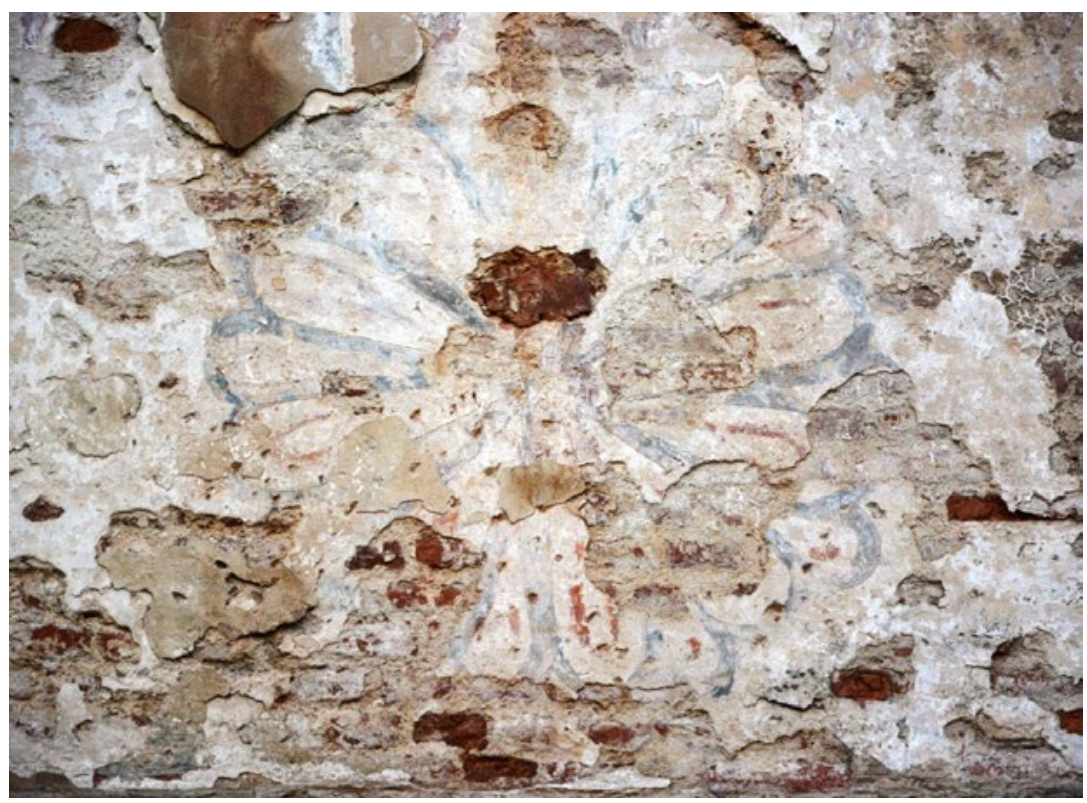

Fig. 4. A large rosette is drawn on the $2^{\text {nd }}$ tier of the outer wall of the corner tower of the Pomoriany castle. Photo by M. Bevz, 2017.

On the walls of the castle are visible traces of bricked-up windows and traces left from annexes, which need to be thoroughly inventoried and identified. The first steps in the identification of the castle building were made several years ago during the completion of the diploma project on the restoration and adaptation of the castle (author of the thesis - A. Vihasty, academic advisor - prof. O. Rybchybskyi, the Department of Architecture and Restoration at Lviv Polytechnic National University) [20]. However, this work is still unpublished.

The preserved ruin presents features of Renaissance architecture with a tall frieze in arcade-style. A careful analysis of the preserved walls shows that these renaissance building forms are not the oldest. They create a newer substance based on older walls, which were built of pieces of stone and had firing ranges in the form of a key for hand-held firearms. We hypothesize that the attic completion of the tower is newer and imposed on older walls (see Fig. 3). An in-depth study of the history of the Pomoriany castle by Alexander Czolowski contains a very valuable plan for the castle complex of the $18^{\text {th }}$ century. On the plan, the tower has a layout scheme in the form of a five-angled defense building, reminding the typical scheme of the "puntone" tower. A comparison of the tower plan in A. Czolowski's documentation (Fig. 2) with the modern plan (Fig. 1) indicates that the three outer walls of the tower were not preserved. Two walls (north and east) were completely lost, and a small fragment remained from the third one. The foundations of the former pentagonal tower have been preserved in the ground and can still be identified today by the topography of the relief.

We found the murals in October 2016 during the inventory and photo-fixing work at the castle within the framework of the master's thesis work of the student Kalyna Havryliv. During the joint exit to the object, the upper layers of the plaster were observed to disappear in many places on the walls of the castle. From under the plaster, we were able to see, in particular, bricked windows with Renaissance carved rosettes on the second tier (in the gallery) were opened (fig. 12, 13).

The paintings were at the height of the second and third tiers on the outer wall of the southeast corner tower (Fig. 1, 3). This tower has been preserved in its reconstructed form. Its northern wall is best preserved and features Renaissance style with the remains of a "blind" arch belt over which, apparently, once had an attic end (sketch at Fig. 2). Nowadays, the upper part of the tower has a cornice end that is dated to the time of the rebuilding of the castle under Jan III Sobieski. The bricks and the eaves are similar to those parts of the castle 
that are identified with the times of reconstructing the castle to the royal palace. The lower part of the tower is made of broken limestone. This is probably the oldest substance. Therefore, the investigated wall of the tower, according to our hypothesis, has three elements that differ in time of construction. Polychrome paintings adorned the second and third tiers of the facade.
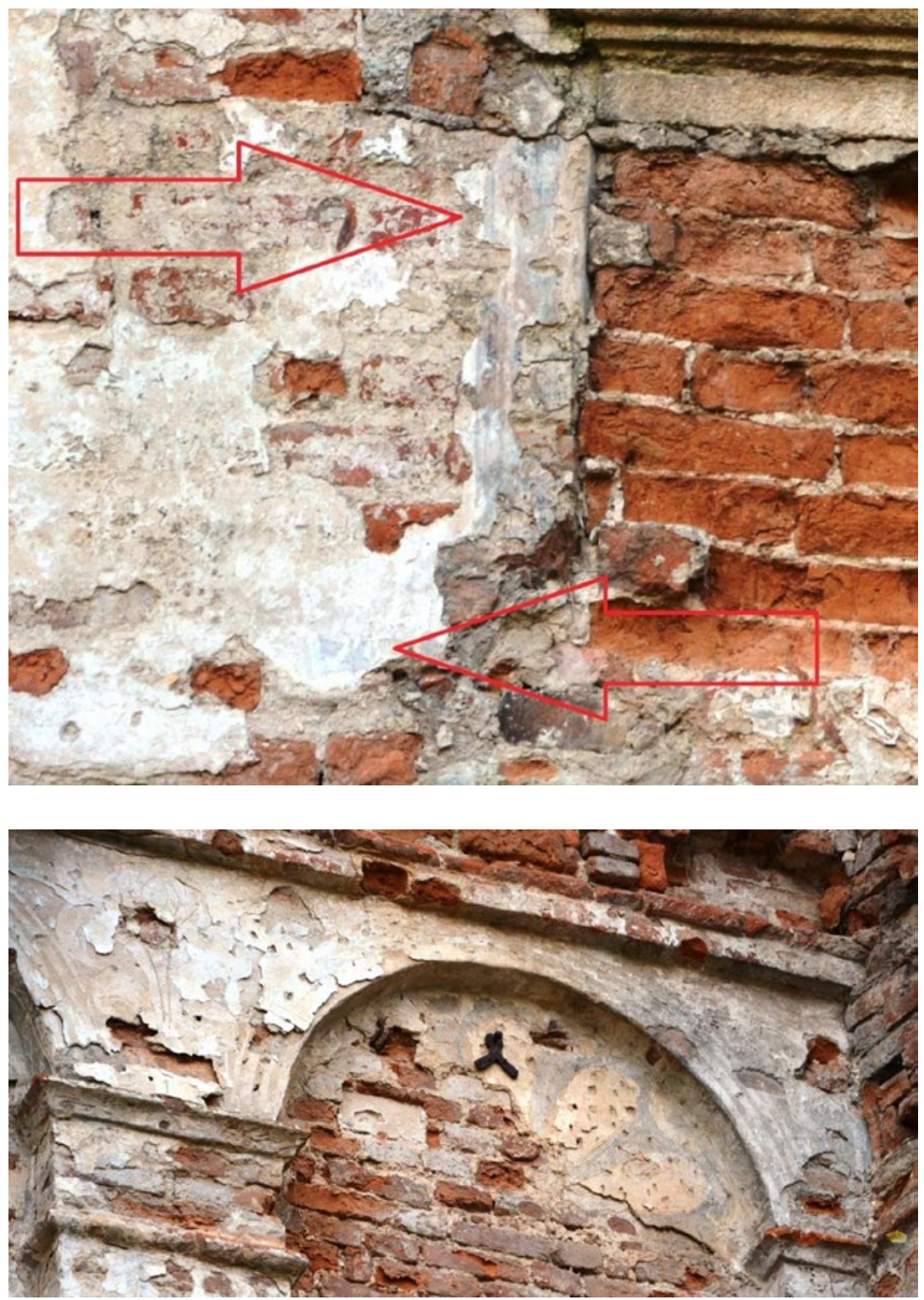

Fig. 5. Vertical hand-drawn painting (arrow 1) near the old bricked-up window opening on the $2^{\text {nd }}$ tier of the outer wall of the Pomoriany castle corner tower. On the left side to the painting remained tiny fragments of some other painting (arrow 2). Photo by M. Bevz, 2017.

Fig. 6. Hand circle-drawn archivolts and half-rosettes in the arch belt on the $3^{\text {rd }}$ tier of the outer wall of the tower. On the left side to the arch are fragments of a rose with branches. Photo by M. Bevz, 2017.

Red, grey, and blue colors dominate in the paintings. The murals are in the state of an emergency. Most of them are lost, although preserved fragments can be used to reconstruct an integral image. The second tier of the tower was painted with rosettes almost two meters in size (Fig. 3), among which were drawn some geometric figures (Fig. 4, 5, 6).

The third tier of the tower, which was built with a blind arcade, was also decorated with polychrome paintings. Their pattern corresponded to the arcade profiling of the wall. Under the arches were painted half-rosettes similar in style to those found on the $2^{\text {nd }}$ tier (Fig. 6, 7). The pilasters had hand-drawn fluting. Their traces are still barely readable. Above the arches, striped archivolts (at seven belts) were drawn in detail. The triangular fields between arches above the pilasters are the most interesting: there is a large rose with symmetric branches (fig. 8). 


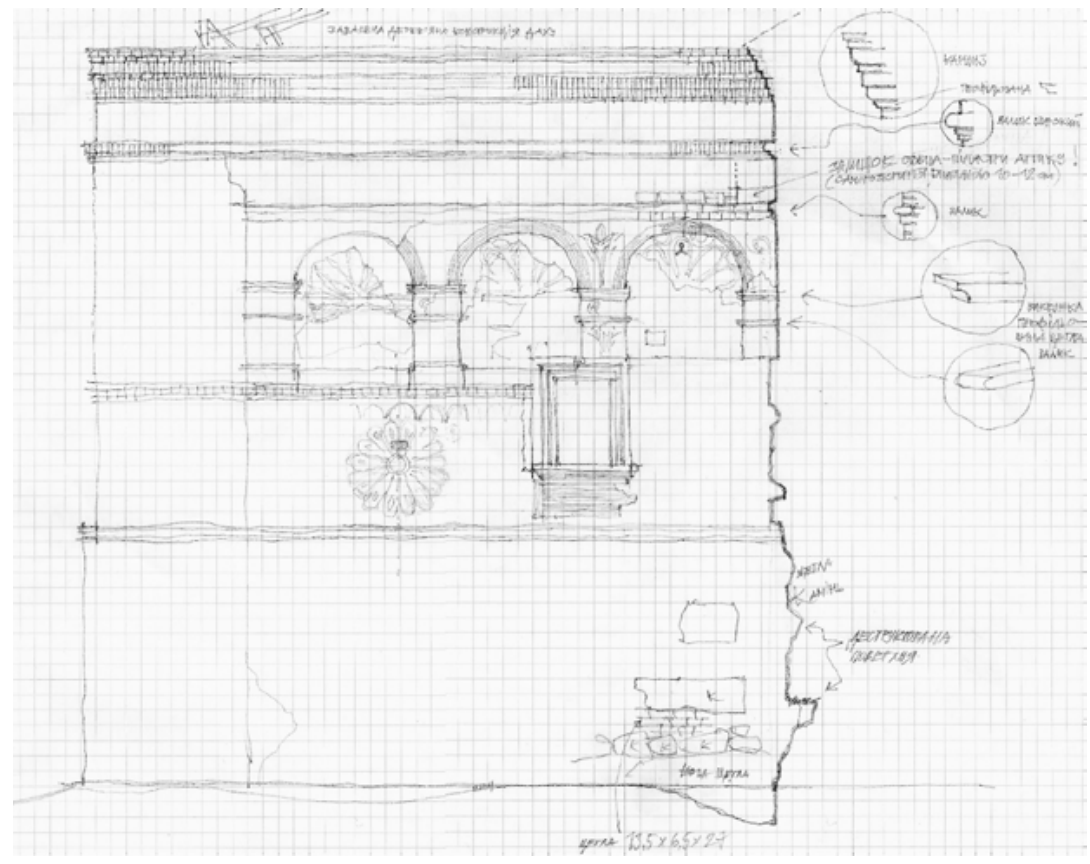

Fig. 7. Field drawing of the preserved part of the wall of the southwest corner tower of the castle in Pomoriany. In the horizontal arcade belt, remnants of polychrome patterns in the form of half-rosettes were fixed. The archivolts of the arches were decorated with colorful lines. In the fields between the archivolts were drawn flower bouquets. Below the arcade belt, hand-drawn rosettes were found between the two horizontal eaves. Their diameter is $120-125 \mathrm{~cm}$. The cornice at the top of the wall is later (from the end of the $17^{\text {th }}$ century) than its lower part with drawings, which can be dated to the and of the $16^{\text {th }}$ or beginning of the $17^{\text {th }}$ century. Made by M. Bevz, 2017.

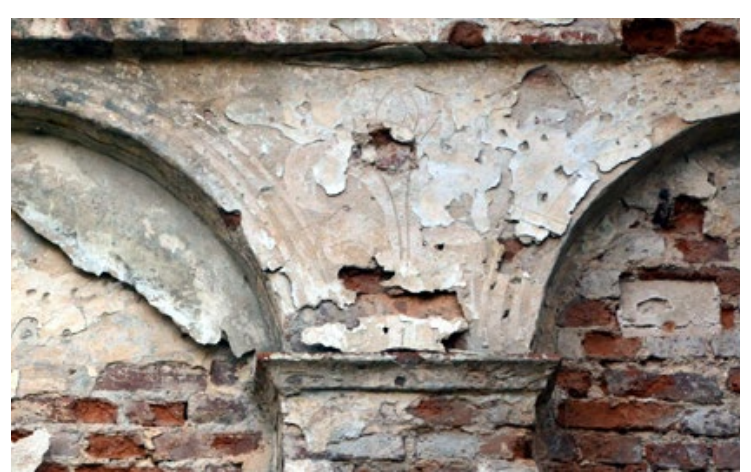

Fig. 8. Hand-drawn rose with branches on the $3^{\text {rd }}$ tier of the outer wall of the tower in Pomoriany castle. Photo by M. Bevz, 2017.

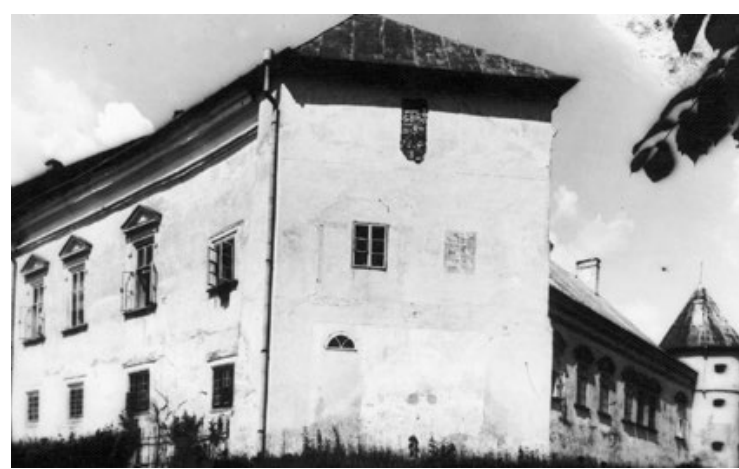

Fig. 9. The castle in Pomoriany. Photo from 1914 [polona. pl]. The place of the lost octagonal tower.

An arch belt was painted above the large rosettes below the cornice. It could still be explored in more detail since only its small fragments can be seen from beneath the preserved upper layers of the plaster. The rest is hidden under the newer layer of plaster (Fig. 2). By carefully removing this plaster, we can see the whole decoration scenery.

In the winter of 2018, due to unfortunate restoration work, the entire southern wing of the palace and the southern wall of the northern part collapsed. The western wall of the northeast tower we are exploring is completely ruined but has not yet collapsed. The photo fixation of the paintings we did September 2019 shows the slow degradation of the paintings due to the rains washing and the disappearance of the outer layer of the plaster that protected them.

As a result of studies of the walls of Pomoriany castle, we found another interesting detail. On the main facade of the castle palace, as a result of the plaster fall, old bricked opening of windows and doors have appeared (Fig. 12, 13). The edges of these old slits are carved out from a limestone. These slots refer to the earlier period of operation of the castle. They were bricked up during the rebuilding of the castle in the time of Jan III Sobieski. The stone decoration of these original frames of windows have a renaissance character in shape and plastic. In particular, the upper beams of these frames have a very interesting carved decoration in the form of rosettes and triglyphs. 

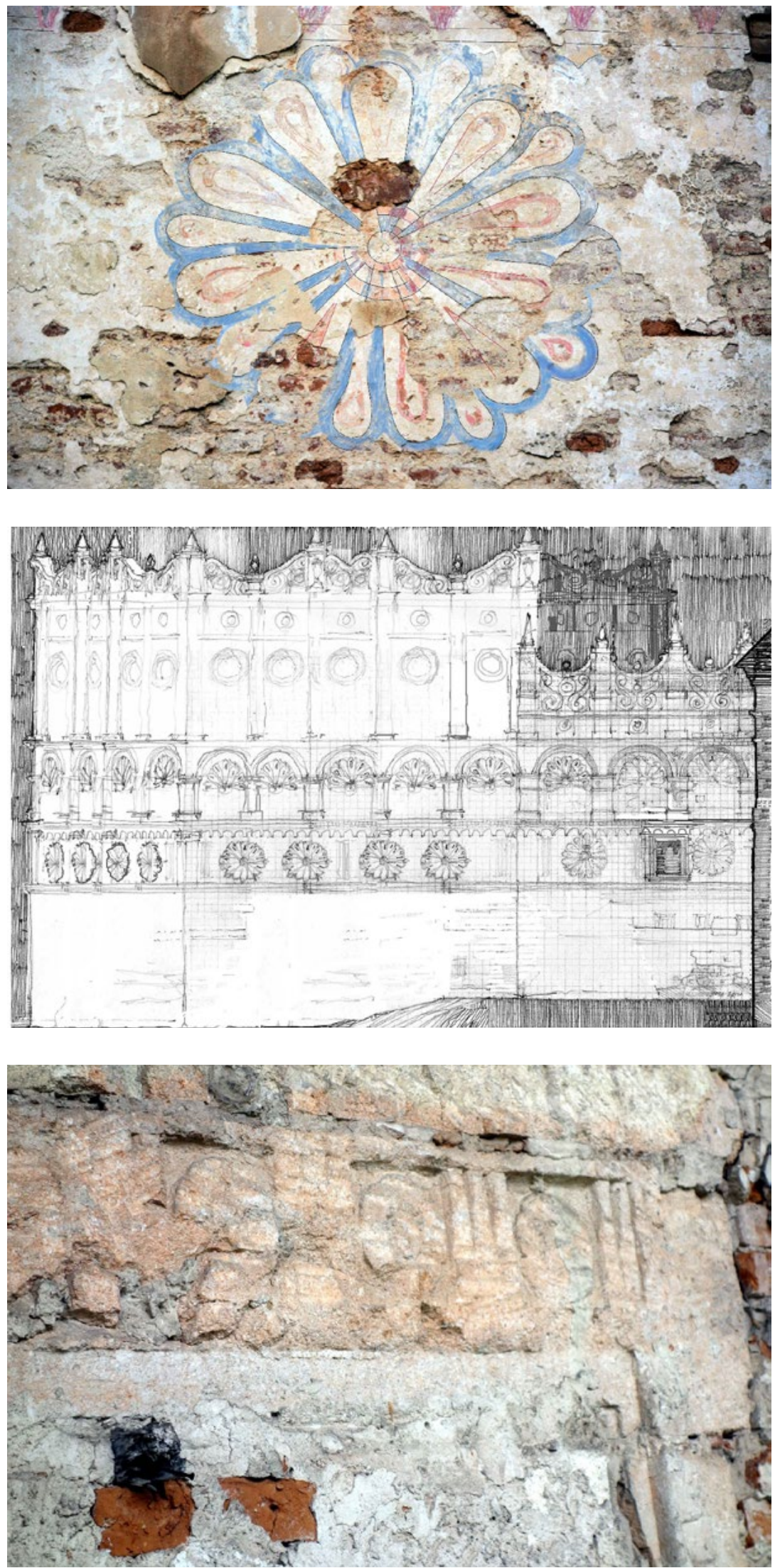

Fig. 10. Photo collage - reconstruction of polychrome painting rosettes on the facade of the castle tower in Pomoriany. Made by M. Bevz, 2019.
Fig. 11. Hypothetic reconstruction of a lost octagonal Renaissance tower (with a polychrome pattern) of Pomoriany castle. Author - M. Bevz, 2017.

Fig. 12. Fragment of the south wall of the castle in Pomoriany. The carved window framing is made in limestone. The scenery is made up of carved rosettes and triglyphs arranged alternately. The carved forms were partially cut down during the rebuilding of the castle in the $17^{\text {th }}$ century. Photo by M. Bevz, 2017. 


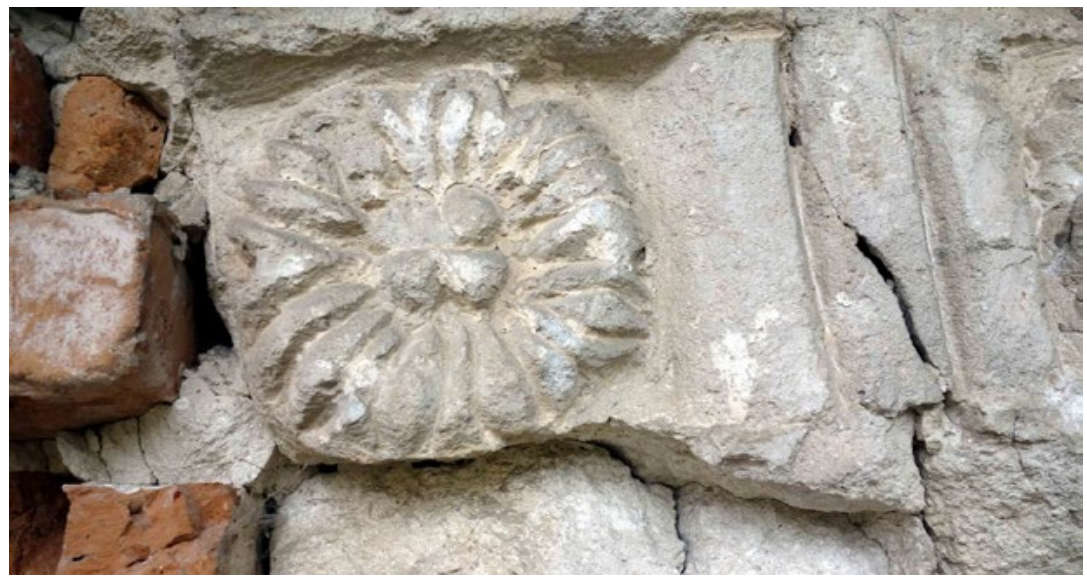

Fig. 13. A well-preserved carved rosette from the window framing of the $16^{\text {th }}$ century. Castle in Pomoriany. Photo by M. Bevz, 2017.

The composition and shape of the carved rosettes and triglyphs are very similar to the rosettes and vertical stripes painted on the facade of the southwestern tower (Fig. 7, 10). From this we can conclude that the detected painted decoration on the walls of the castle was made, looking at the carved scenery. That is, the painted and carved decoration of the castle walls were created in stylistic unity.

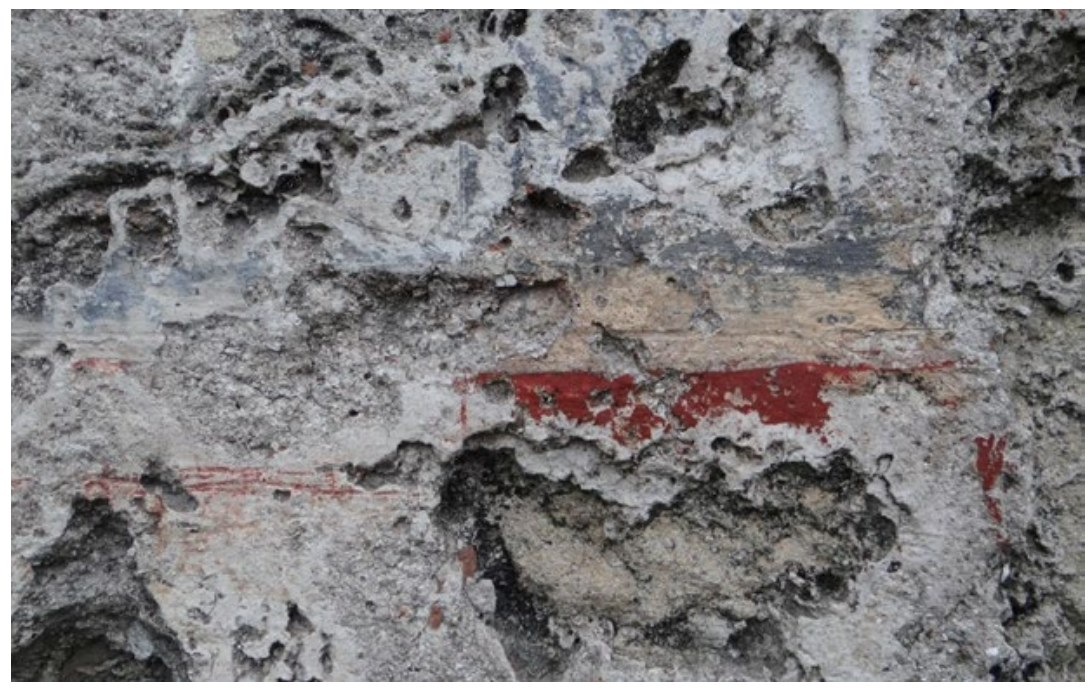

Fig. 14. Fragments of paintings at the outer wall of the castle in Yazlivets. Photo by M. Bevz, 2017.

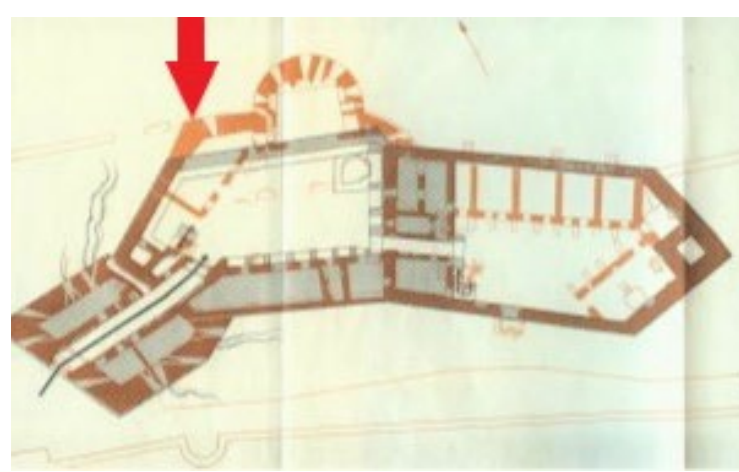

Fig. 15. Location of the found fragment of polychrome painting at the plan of Yazlivets castle (the plan is taken from the publication of B. Queguin [9, p. 113])

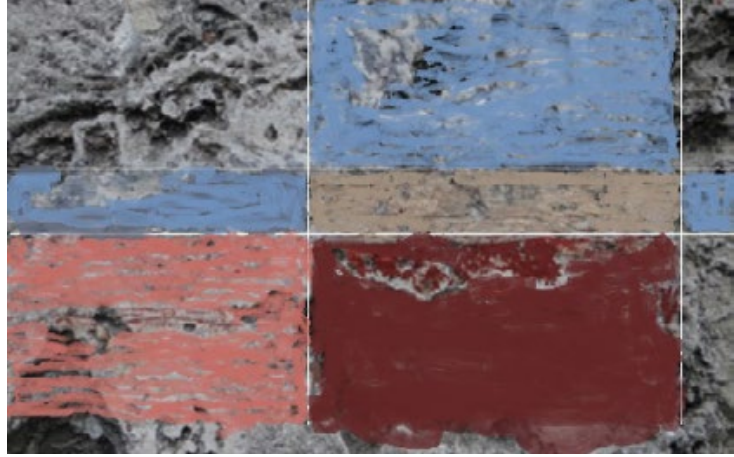

Fig. 16. Reconstruction of the colored scheme of decoration on the walls of Yazlivets castle. M. Bevz, 2019. 
The tradition of exterior murals on the walls of the Pomoriany castle has proven to be very enduring. An interesting fact is finding photographs from the early twentieth century, which depicts a dummy painted window on the second tier of the same tower but on its north wall (Fig. 9). This is undoubtedly a later painting decoration. It comes from the time when the tower was already partially dismantled and plastered again. On the newly built part of the tower, a fake window was painted to give a symmetrical composition to the facade. It happened, probably at the end of the 18 - early 19 century. Similar drawings of dummy architectural decorations and elements are known from other objects. Large dummy framed windows were painted on the walls of the second tier. They decorated the lost gallery with a colonnade of Zhovkva Castle after its rebuilding in the $18^{\text {th }}$ century. We were able to fix the polychromy of these windows in the late 1990s. Nowadays, these murals are already completely lost. Similar painted window decor is on the walls of Pidhirtsi Castle at the junction of the second tier with the terrace on the south side of the palace (Fig. 17, 18). In our opinion, these paintings should also be dated to the eighteenth century.

Very small remains of external paintings we discovered on the northern walls of the castle in Yazlivets, Ternopil region. Yazlivets castle has a more researched architectural history $[4,5,6]$ than the one in Pomoriany. An outline of his history was covered by Alexander Czolowski [4], and in the interwar period, the castle was thoroughly surveyed and archaeologically investigated. At the same time, its measurements were carried out by a group led by Bogdan Queguin [6]. However, none of the researchers paid attention to the preserved small fragments of polychromy on the north outer wall of the castle. Fragments of the paintings were discovered and recorded by us in 2011, thanks to the attention of architect-restorer Volodymyr Bevz.

Unlike the Pomoriany castle, fragments of paintings in Yazlivets are in the lower tier on the straight section of the northern defensive wall between the semicircular tower and the corner (Fig. 14).

Unfortunately, only small fragments of polychrome survived, so it is unlikely to reconstruct the decoration. However, all fragments of the preserved plastering of the castle are worth examining in detail to determine the remains of polychrome. The preserved fragment shows a geometric pattern (Fig. 16) in several colors (red, grey, blue, white, and ochre). It looks like it was an orthogonal grid of colorful lines that was combined with some other elements of the plant or figurative nature.

Our studies of the architecture of the castle complexes of Western Ukraine have revealed another way of polychrome decoration of the exterior facades. It is a way of drawing illusory architectural details (the socalled picturesque «delusions») to give the facade the desired compositional unity or balance. Most often, the subject of such drawings were dummy windows or decorative elements. At the same time, window fillings with glass, wooden frames, stucco frames could be imitated by painting. It could also be imitations of sticky decorative elements - cartouches, lintels, cornices, etc. We found an example of such a picture in the analyzed castle in Pomoriany. Photo of the castle from the beginning of the $20^{\text {th }}$ century (fig. 9) we see the south wall of the tower, at the level of the second tier, which has two windows. One is true, and the other is drawn to give symmetry to the facade.

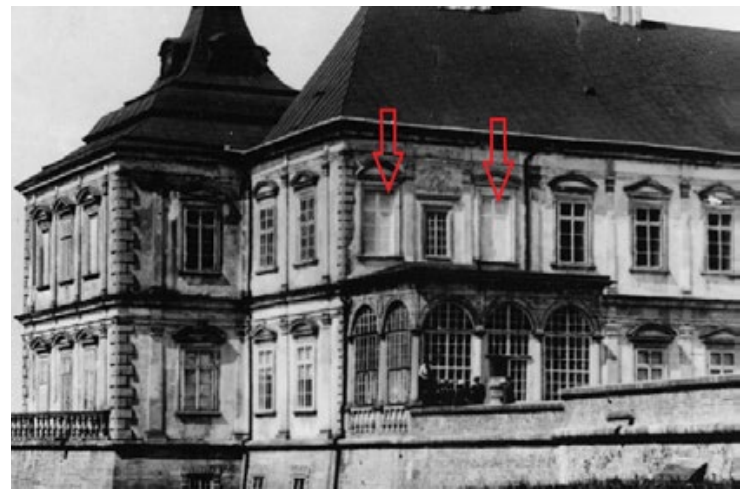

Fig. 17. The southern facade of the castle in Pidhirtsi. Our marking with arrows of fictitious painted windows (photo from the interwar period) [retroua] [11].

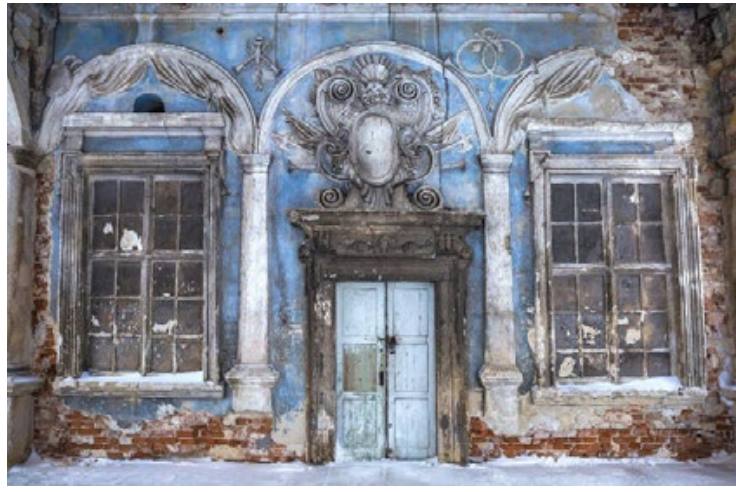

Fig. 18. Photo of stucco and painted fictitious windows on the eastern terrace of the castle in Pidhirtsi (present state). Photo by E. Shavlovska [12]. 
This technique was particularly well applied in Zhovkva Castle. When in the $18^{\text {th }}$ century, the main facade of the palace was completely reconstructed with attachment of stairs and two-tier gallery (fig. 19), then in the side wings of the gallery on the second floor were framed by three dummy windows - made in the technique of murals very professionally. Looking at the palace from the castle courtyard, it was difficult to distinguish between the real windows and the painted ones. Unfortunately, these picturesque windows have been lost in recent years. We have taken photos of their remains in 2012 (fig. 20). We find a similar solution to the palace in the Pidhritsi castle. The object is very known in the history of architecture. The relatively well-preserved windows are located in the lateral risalites of the south facade at the door overlooking the terrace (fig. ). The restoration works of these painted architectural elements should be taken into account in the ongoing restoration work of the Zhovkva castle facades. In Pidhirtsi Castle, these works require professional restoration.

We know of another way of artistic painting of facades. This is an artistic «domestication» of the shadow effects of the stucco architectural decoration. The remnants of this type of painting were found by professor Oleg Rybchynskyi in the study of the facades of the Baroque church in Uhniv. This rare technique was used in the late $17^{\text {th }}$ century by architect Lenartowicz (from Lublin), trying to enhance the visual effect of deep shadows on the elements of the front decor of eaves, lintels, pilasters, round-bar drafts, etc. [17]. The decorative elements were made in the technique of plaster drawing and, subsequently, in the fresco technique were painted artificial shadows.

Our research shows that in the past, architects not only painted the walls of buildings and their elements in different colors. They often used polychrome as a means of art, artistic decoration. Such methods of artistic furnishing of facades of residential buildings (which had hand-drawn geometric, floral ornaments, or also scene scenes with figures of saints, etc.) are known in many historical cities in Europe. We also know about such polychrome murals on the market building in the Market Square in Lviv (Rynok 31). The above examples of murals in castles in Pomoriany and Yazlivets for the first time have shown that this method of decoration was applied even in defense buildings.

In the Renaissance, another very common way of decorating the facades was spread - the sgraffito technique. This is a sophisticated wall decorating technique. It consists of the initial covering of the wall with several layers (often two) of painted plaster. Each layer of plaster was given a different color. Subsequently, the top fresh wet layer of the top plaster was scraped in the right places (according to the preliminary drawing) with sharp tools. In this way, the color of the lower plaster was revealed in the tattered parties. This way is possible to obtain a two - or several-color composition. Most often, in this way, decorate the facade with geometric ornaments and simple motifs of garlands, rosettes, plants, flowers, etc. [18: c. 378]. Skillful masters in the technique of sgraffito even performed figure compositions and paintings depicting every day or mythical subjects. The Renaissance castle in Krasiczyn in eastern Poland has preserved and professionally restored two-tone compositions on the exterior facades. Facade decoration in the sgraffito technique was very popular in Lublin in the $20^{\text {th }}$ century.

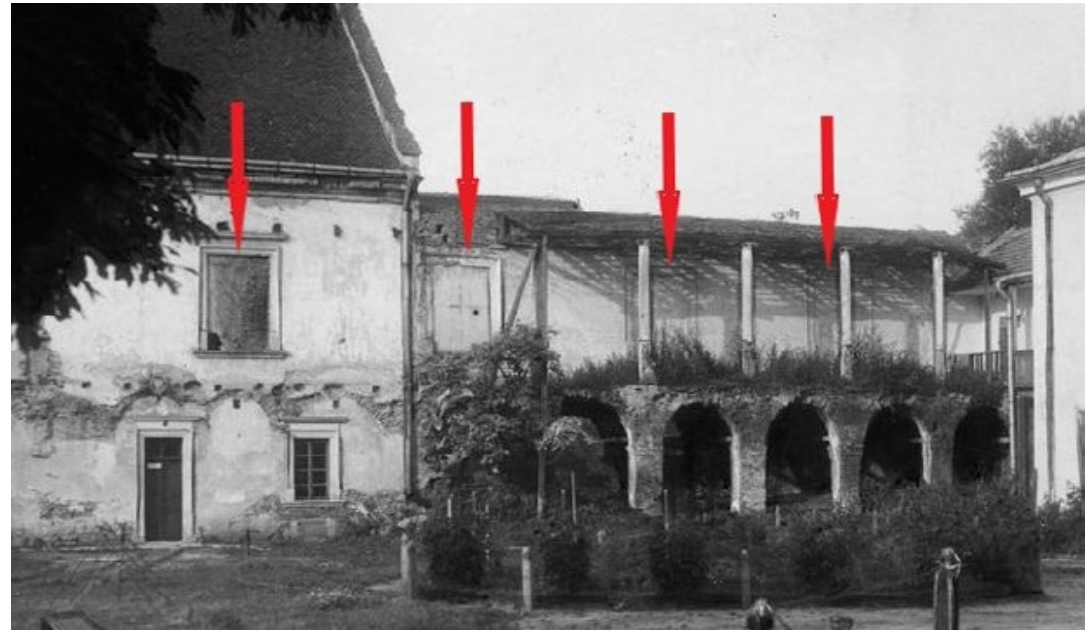

Fig. 19. The elevation of the castle palace in Zhovkva. Photo of beginning $20^{\text {th }}$ cent. 


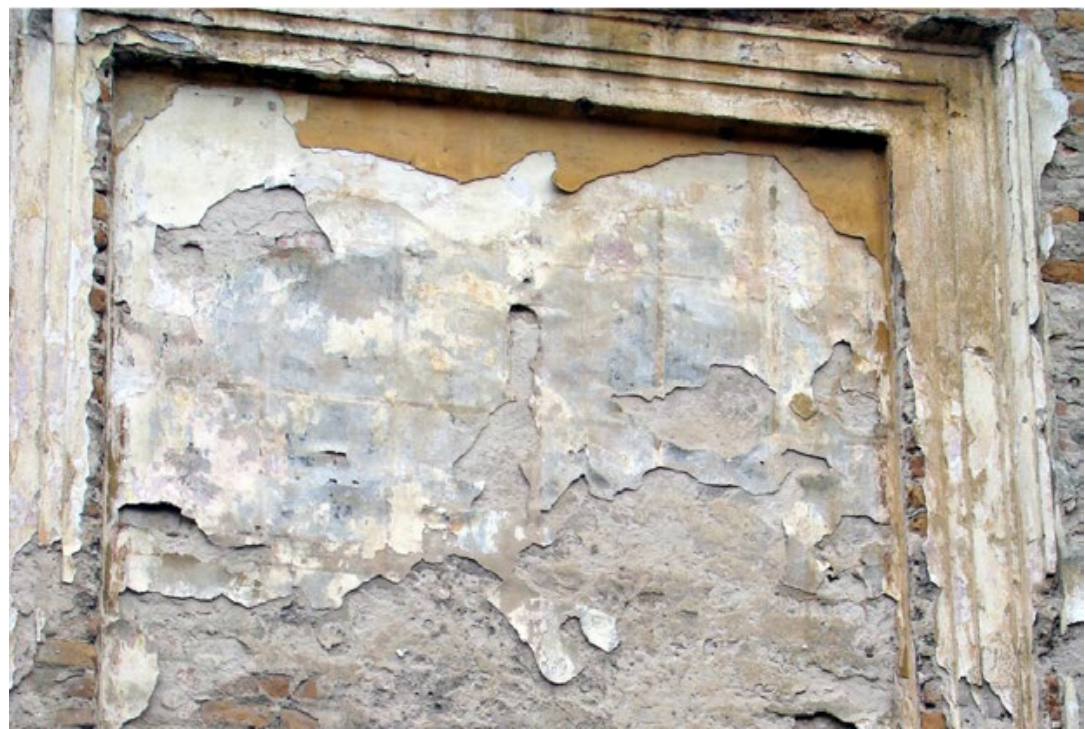

Fig. 20. Photo of the remains of artistic fictional paintings (the window) on a wall of the castle in Zhovkva. Photo by M. Bevz, 2012

Decorating the walls of the Pomoriany castle was another simpler way. The technique of wall painting decoration can be scribed as:

Apply two layers of plaster and smooth it to a perfectly flat surface.

- Drawing on a flat moist surface a plaster drawing with a sharp tool; rulers and compasses were used;

- Scraping of those parts of the drawing that were to serve as the background, the top thin layer of plaster, giving it the character of the textured surface (Fig. 8);

- Application of polychrome composition with brushes, using water-soluble paints. Paints were applied on clean, non-textured surfaces. These features can be seen in the photo fig. 4, 5, 6. When drawing rosettes and buds, two colors were red and blue. However, in many places, these colors were mixed. As a third color, masters used whitewash. We selected samples of plaster and paint and submitted them for laboratory analysis. It should also be noted that pigment may have been added to the top layer of the plaster. The plaster has a light yellowish-golden hue (Fig. 6).

- The plaster with polychrome paintings was «chipped» with a hammer, and a new layer of lime-sand plaster was applied to it. In our view, this happened when the castle was rebuilt in the late $17^{\text {th }}$ century when the castle was owned by Jakub and later by Jan Sobieski. Two new layers of plaster are traced to this new layer. The last one is the cement. A very interesting fact is that in some places on the thin first layer of the plaster (the one laid on the found paintings), traces of marking under new paintings with weak traces of the paint layer (Fig. 8) were found. That is, we have arguments that the original paintings of the early $17^{\text {th }}$ century have been updated with a change of pattern. However, it is not possible to read this figure, since this layer is very low in open areas. But in the areas below the later plaster, one can hope to find these two layers of polychrome paintings.

- The paintings were also on the pilasters on the second tier of the tower. This is evidenced by traces of line marking on the pedestal. Unfortunately, the paintings themselves are preserved only under the pedestal eaves in the form of lines of blue and red. Alternately placed remnants of spots of blue and red were also found on the cornices above the blind arcade. It was probably a polychrome imitation of the denticles in the cornice. A more detailed examination of pilasters and other parts of the wall is required, but using scaffolding.

- The condition of plaster with polychrome paintings is an emergency. Because the top of the wall has no roof, the painting is washed away and destroyed by rain, snow, and frost. 


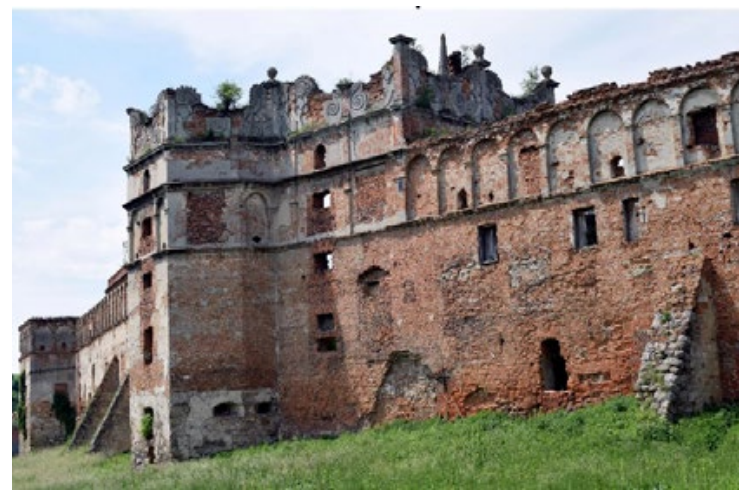

Fig. 21. Castle in the village of Stare Selo. Photo by M. Bevz, 2019.

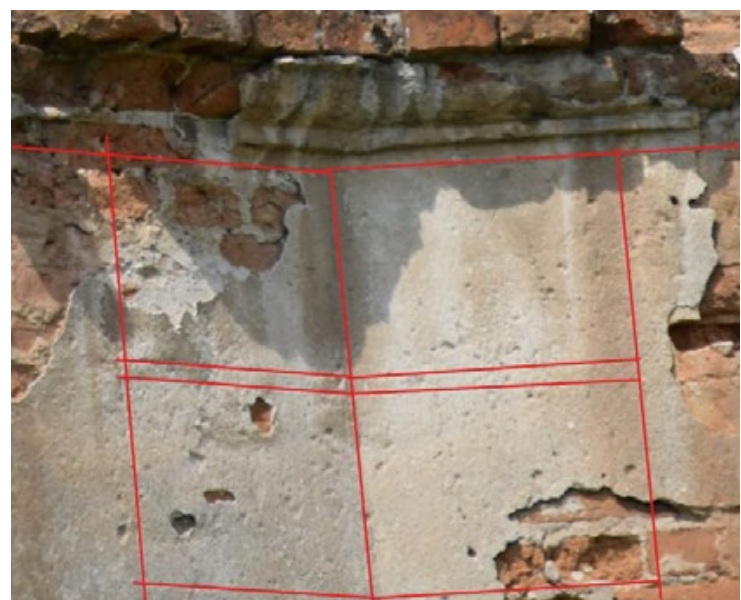

Fig. 23. The fragment of the outer wall of the west wall of the Stare Selo castle. The lines indicate the marking on the plaster for painting. Photo by M. Bevz, 2019.

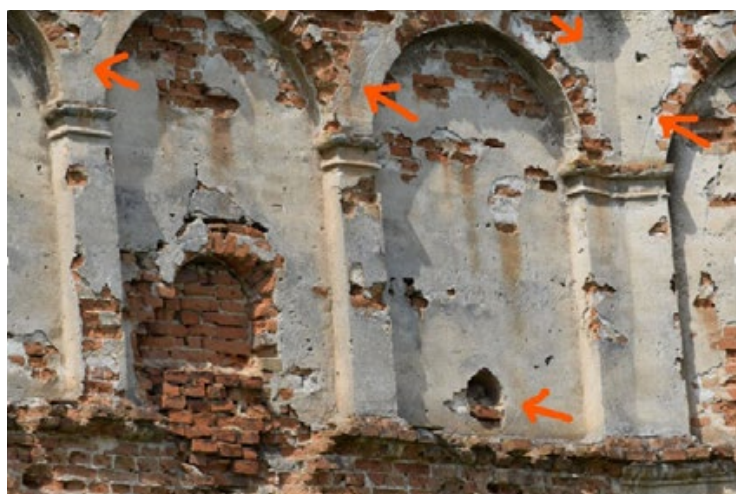

Fig. 22. The photo of the arcade belt of the upper part of the outer wall of the Stare Selo castle. Arrows indicate traces of marking for painting on plaster. Photo by M. Bevz, 2019.

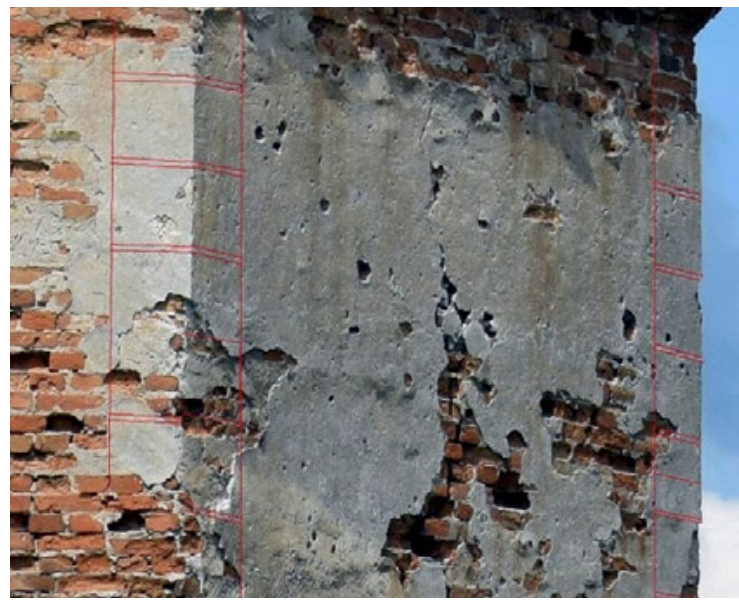

Fig. 24. Fragment of the outer wall of the southwestern tower of the Stare Selo castle. The lines indicate the marking on the plaster for painting. Photo by M. Bevz, 2019.

We found another example of decorating the castle walls using paintings. This decoration found in 2019 in the Stare Selo castle. This is a castle that was built in the late $16^{\text {th }}$-early $17^{\text {th }}$ century. Saved in ruins. Its architectural appearance has not been much changed in subsequent periods. Therefore, this castle is analogous to the castles in Pomoriany and Yazlivets. In particular, the architecture of the castle towers in Stare Selo is very similar to that of the Pomoriany Castle tower. The towers of these castles have the same granular plan and the same type of attic tops. On the outer walls of the southwestern tower and on the wall of the south gate, we find the remains of markings under polychrome scenery. This scenery had the character of a geometric ornament (Fig. 21-24).

\section{Conclusions}

The results of our pilot studies on polychrome paintings in two castles show very interesting ways of decorating the castle facades. Based on a visual assessment of the stone substance of castles, we date these paintings to the seventeenth century. The paintings found should be very carefully inventoried and examined, including laboratory tests. Small fragments of polychrome paintings on the two castles were fixed at the last moment. If no rescue work is carried out, these fragments will disappear in two to three years. Based on our discoveries, we can suggest that a similar way of decoration could be found in other Western Ukrainian castles. Particular 
attention should be paid to the polychromy detection of castles in Ostroh, Medzybizh, Berezhany, Dobromyl and other. These castles were built in the late $16^{\text {th }}$ - early $17^{\text {th }}$ centuries. And their architectural design is similar to the castle in Pomoriany.

Our research shows that in the past, architects not only covered the walls of buildings and their elements in different colors. They often used polychrome as an artistic decoration. The above examples of murals in castles in Pomoriany, Yazlivets, Zhovkva, Pidhirtsi are shown that this method of decoration was applied even in defense buildings.

The preserved fragmentary paintings of the Pomoriany castle should be conserved as an interesting example of the decoration of the castle facades in the $17^{\text {th }}$ century. More detailed research and conservation of the murals would be good to do immediately. More detailed researches and conservation of the remains of the paintings at all the presented castles should be carried out.

\section{References}

[1] Aftanazy, Roman. Dzieje rezydencji na dawnych kresach Rzeczypospolitej. Województwo Ruskie, Ziemia Halicka i Lwowska, T. 7, wyd. 2 przejrzane i uzupełnione, Zakład Narodowy im. Ossolińskich. Wrocław, Warszawa: 1995, s. 494-502.

[2] Bevz, Mykola. Pro znachidku maliarskoji dekoratsii na zownishnich stinach u zamku w Pomorianach i Yazliwtsi [w] Current Issue in research, conservation and restoration of historic fortifications. Collection of scientific articles, N 8, Lviv-Chełm, 2016, s. 28-33.

[3] Materialy do dziejow miasta Pomorzany. Zebrane przez Aleksandera Czołowskiego. https://polona.pl/item/materialy-do-dziejow-miasta-pomorzany-zebrane-przez-aleksandra-czolowskiego,MzEzNDA5MDU/350/\#info:metadata

[4] Czołowski Aleksander. Dawne zamki i twierdze na Rusi Halickiej. Teka Konserwatorska. Rocznik Koła C.K. Konserwatorów Staroźytnych Pomników Galicyi Wschodniej. - Lwów, 1892. - s. 83-85.

[5] Czołowski Aleksander. Przeszłość i zabytki województwa Tarnopolskiego / A. Czolowski, B. Janusz. - Tarnopol: Wyd-wo Tarnopolia, 1935. - $104 \mathrm{~s}$.

[6] Queguin, Bohdan. Zamek Jazłowiecki. Studia i materiały do teorii i historii architektury i urbanistyki. - T. II. - Warszawa: PWN, 1960. - s. 113.

[7] Havryliv, Kalyna. Conservation and Revitalization of Castle in Pomoriany. Master Thesis. Under promoting prof. B. Szmygin, M. Bevz. Lublin University of Technology, 2017.

[8] https://polona.pl/item/14674131/0/ access 28.04.2017. zdjecie 1925. Biblioteka Narodowa.

[9] https://polona.pl/item/pomorzany-najstarsza-czesc-zamku,MTQ2NzQxMzE/1925, tekst on the back side -16 w. (access 27.11.2019).

[10] https://pl.wikipedia.org/wiki/Zamek_w_Pomorzanach (access 20.11.2016).

[11] https://retroua.com/pidhirtsi/7304-pidhoretskyizamok (access 18.11.2019).

[12] https://unexploredcity.com/blog-pidhoretskyi-zamok-zamok-z-pryvydom/ (access 18.11.2019).

[13] https://uk.wikipedia.org/wiki/Поморянський_замок (access 20.11.2016).

[14] Matsiuk, Orest. Zamky i fortetsi Zachidnoji Ukrainy, Lviv: Tsentr Europy, 2005, p. 33-35.

[15] Orlowicz M. Ilustrowany przewodnik po Galicyi. Wydał Dr. Karol Kwieciński. - Lwów: 1919. - s. 122-123.

[16] Rybchynskyi O. Materialy kompleksnych peredproektnych doslidzhen. Eskiznyj proekt restavratsii kostelu Uspinnia Bohorodytsi XVII st. v misti Uhnovi. NULP, NDL-104, archiv kafedry architektury i restavratsii. 2007 r.

[17] Słownik geograficzny Królestwa Polskiego i innych krajów słowiańskich. Tom VIII. - s. 747-753.

[18] Vechersky V. Fortetsi i zamky Ukrainy. - Kyiv, 2011. - p. 491.

[19] Andriy Vihastyi, academic advisor - assoc. prof. O. Rybchybskyi, diploma Thesis "Restoration of castle of Pomoriany", Archive of the Department of Restoration of Architectural and Art Heritage, Lviv Polytechnic National University. 